\title{
A NOVEL APPROACH FOR DEVELOPING HIGH-RESOLUTION SUB-FOSSIL PEAT CHRONOLOGIES WITH ${ }^{14} \mathrm{C}$ DATING
}

\author{
T H Donders ${ }^{1,2} \bullet \mathrm{F}_{\text {Wagner }}{ }^{1} \cdot \mathrm{K}$ van der Borg ${ }^{3} \bullet \mathrm{A} \mathrm{F} \mathrm{M} \mathrm{de} \mathrm{Jong}^{3} \bullet \mathrm{H}^{\text {Visscher }^{1}}$
}

ABSTRACT. Sub-fossil sections from a Florida wetland were accelerator mass spectrometry (AMS) dated and the sedimentological conditions were determined. ${ }^{14} \mathrm{C}$ data were calibrated using a combined wiggle-match and ${ }^{14} \mathrm{C}$ bomb-pulse approach. Repeatable results were obtained providing accurate peat chronologies for the last 130 calendar yr. Assessment of the different errors involved led to age models with 3-5 yr precision. This allows direct calibration of paleoenvironmental proxies with meteorological data. The time frame in which ${ }^{14} \mathrm{C}$ dating is commonly applied can possibly be extended to include the 20th century.

\section{INTRODUCTION}

Modern paleoclimatology focuses on the development and validation of biological proxies, which are indicative for climate parameters rapidly changing under ongoing greenhouse gas forcing. The ability to understand the dynamics of major weather determining systems such as the El Niño Southern Oscillation (ENSO) is a basic requirement to predict the consequences of human interference with the global system. Although increasing amounts of instrumental precipitation and temperature records are available, the relatively short timespan covered in these records generally does not encompass the total range of natural variability.

On this background, the development of proxies able to detect high-frequency changes on nearannual to sub-decadal scale is needed. To test the applicability of any potential proxy, it is essential to first assess the natural range of variability within a single site and compare changes to meteorological data.

Among the available proxies for paleoclimatological reconstructions, pollen and plant macroremain analysis have been demonstrated to be highly indicative for fast changes in their growth environments (Birks and Birks 2003). Peat-accumulating systems provide well-preserved organicrich sediments and are, thus, a suitable source for paleobotanical investigations.

Validation and application of these proxies, for studies involving climatological changes occurring on multi-annual to sub-decadal scale, requires meticulous calibration of paleo-records with modern meteorological data series. The proxy quality thereby strongly depends on an extremely accurate age assessment of young sediment cores. Contrary to lake sediments, peat is generally not (annually) laminated. Consequently, radiometric dating is required to obtain a reliable core chronology.

Commonly used ${ }^{137} \mathrm{Cs}$ and ${ }^{210} \mathrm{~Pb}$ dating methods depend on analysis of particles that potentially migrate in the sediment due to changing water levels, and the results are not always satisfactory (Jensen et al. 2002) or in mutual agreement (Cohen et al. 1999). Errors in determination of water content and dry bulk densities and the estimation of initial concentrations provide further uncertainties in ${ }^{210} \mathrm{~Pb}$ dating (Appleby 2001). In this study, we assess the applicability of radiocarbon dating in creating high-precision peat chronologies for the 20th century and into the time frame where ${ }^{14} \mathrm{C}$ dating is commonly applied. Furthermore, we consider the different errors involved and provide some recommendations for future application.

${ }^{1}$ Botanical Palaeoecology, Laboratory of Paleobotany and Palynology, Utrecht University, Budapestlaan 4,
3584 CD Utrecht, the Netherlands.
${ }^{2}$ Corresponding author. Email: t.h.donders@bio.uu.nl.
${ }^{3}$ R.J. Van de Graaff Laboratorium, Utrecht University, Princetonplein 5, 3584 CC Utrecht, the Netherlands.

(C) 2004 by the Arizona Board of Regents on behalf of the University of Arizona

Proceedings of the 18th International Radiocarbon Conference, edited by N Beavan Athfield and R J Sparks

RADIOCARBON, Vol 46, Nr 1, 2004, p 455-463 


\section{SITE DESCRIPTION}

Extensive peat-accumulating wetlands exist in southern Florida (USA). This area is highly suitable for high-resolution studies on climate variability because of the distinct linkage of precipitation and temperature to the ENSO system (Cronin et al. 2002). High-quality ecological and meteorological data for the region are abundant. The site studied is located in a relatively undisturbed wetland ecosystem, part of the Fakahatchee Strand Preserve State Park $\left(25^{\circ} 95^{\prime} \mathrm{N}, 81^{\circ} 49^{\prime} \mathrm{W}\right.$, hereafter FSPSP, see Figure 1).

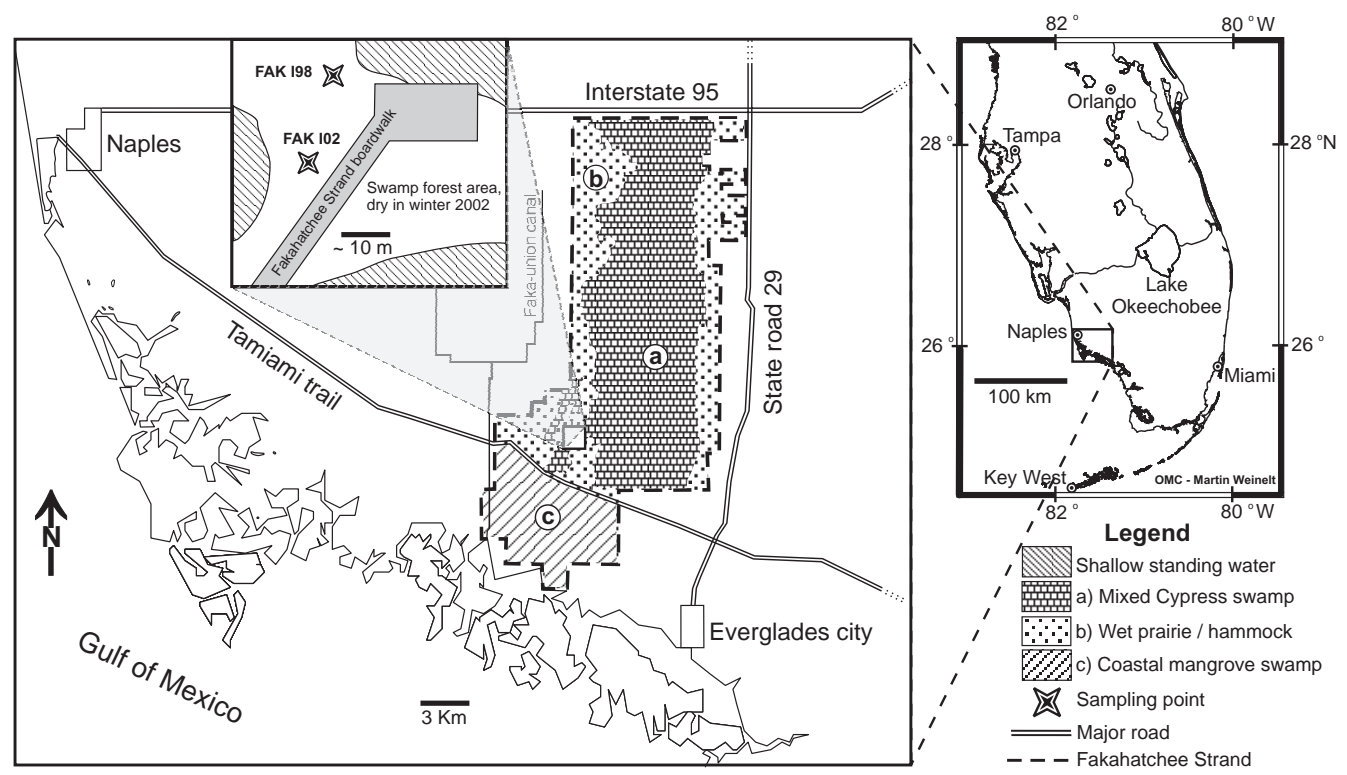

Figure 1 Location and environmental setting of the Fakahatchee Strand Preserve State Park (FSPSP) in south-central Florida

Although widespread in Florida, human impacts by lumbering and drainage activities have not directly affected the area studied; old-growth forest is still dominant (Burns 1984). Swamp conditions persist within the wide and shallow 40-km-long karst structure or "strand" where a peat layer seals off the underlying limestone. This organic-rich layer retains water which extends the local hydroperiod. These continuous moist conditions create anoxia that inhibits organic degradation and bioturbation. The strong seasonality, however, creates large fluctuations in water level throughout the year, which allows small inorganic particles to migrate within the sediment column. The wetland forest ecosystem and general low topography of the terrain (Watts and Hansen 1994) act together as a water capacitor, resulting in a wide sheet flow that deposits no clastic material and creates stable high sedimentation rates. These factors combined make the FSPSP highly suitable for collecting organicrich undisturbed sediments for both ${ }^{14} \mathrm{C}$ dating and subsequent paleoecological reconstructions.

\section{MATERIAL AND METHODS}

\section{Coring and Sampling Procedures}

Two peat cores were taken in the FSPSP for palynological/paleobotanical studies. The first peat core was taken in 1998 (FAK 198) from the end of a 300-m FSPSP boardwalk that penetrates into an undisturbed mixed cypress forest. The 43-cm-long core was frozen and cut into 1-cm slices for further analysis. A second core (FAK I02) was collected in 2002 at approximately $50 \mathrm{~m}$ from FAK 198 
in a slightly deeper and wetter section of the swamp. This $83-\mathrm{cm}$ core was cut in $0.5-\mathrm{cm}$ slices for more detailed analysis. Both cores were taken with a manual 21 -cm-diameter peat corer designed for minimal sediment disturbance (Clymo 1988). The obtained peat sequences consist of dark, organic-rich, non-laminated peat with abundant leaf and plant fragments. Tops were not consolidated and contained the best-preserved plant remains. The peat slices were sub-sampled for AMS ${ }^{14} \mathrm{C}$ dating, plant macrofossil-analysis, pollen analysis, and loss-on-ignition (LOI, FAK I02 only).

For AMS ${ }^{14} \mathrm{C}$ dating, leaf samples from 9 slices of core FAK I98 and 10 slices of core FAK I02 were picked out and determined to highest possible taxonomic level (see Table 1 for details). Material from tall canopy trees (Quercus and Taxodium) was used exclusively to eliminate reservoir effects from any old carbon outgassing and subsequent uptake by low-growing vegetation. The remains were cleaned from any rootlet material that might contaminate the samples, dried for $12 \mathrm{hr}$ at $60^{\circ} \mathrm{C}$, and stored in dry and cool conditions.

Table 1 Samples and results of AMS ${ }^{14} \mathrm{C}$ dating.

\begin{tabular}{|c|c|c|c|c|c|c|c|}
\hline $\begin{array}{l}\text { Depth }^{\mathrm{a}} \\
(\mathrm{cm})\end{array}$ & $\mathrm{UtC} \# \mathrm{~b}$ & Material & $\begin{array}{l}\text { Dry weight } \\
(\mathrm{mg})\end{array}$ & $\begin{array}{l}\delta^{13} \mathrm{C} \\
(\%)\end{array}$ & $\begin{array}{l}{ }^{14} \mathrm{C} \text { age } \pm 1 \sigma \\
(\mathrm{yr} \mathrm{BP})\end{array}$ & $\begin{array}{l}\text { Calibrated ages } \\
(\text { cal } \mathrm{AD} \pm 1 \sigma)\end{array}$ & $\begin{array}{l}\text { Total error }{ }^{\mathrm{C}} \\
(\mathrm{yr})\end{array}$ \\
\hline \multicolumn{8}{|c|}{ Core FAK I98 } \\
\hline 4 & 11709 & leaf (Quercus / Acer) & 2.17 & -30.7 & $-1018 \pm 34$ & $1993 \pm 3^{d}$ & 5 \\
\hline 6 & 11710 & leaf (Quercus / Acer) & 1.31 & -32.6 & $-877 \pm 27$ & $1995 \pm 3^{d}$ & 5 \\
\hline 9 & 11711 & leaf (Quercus / Acer) & 2.08 & -29.8 & $-1476 \pm 27$ & $1985.5 \pm 2.5^{\mathrm{d}}$ & 4.5 \\
\hline 12 & 11712 & leaf (Quercus / Acer) & 0.59 & -29.7 & $-1522 \pm 31$ & $1985 \pm 2^{d}$ & 4 \\
\hline 15 & 11713 & leaf (Quercus / Acer) & 0.45 & -29.9 & $-1671 \pm 32$ & $1983 \pm 2^{d}$ & 4 \\
\hline 20 & 11714 & leaf (Quercus / Acer) & 0.2 & -28.1 & $-1507 \pm 70$ & $1960.5 \pm 1.5^{\mathrm{d}}$ & 3.5 \\
\hline 23 & 11715 & seed (cf. Quercus) & 2.29 & -26.7 & $-353 \pm 29$ & $1955 \pm 1^{\mathrm{e}}$ & 3 \\
\hline 26 & 11716 & leaflets (Taxodium d.) & 1.01 & -28.9 & $-100 \pm 70$ & $1954 \pm 1^{\mathrm{e}}$ & 3 \\
\hline 39 & 11717 & leaflets (Taxodium d.) & 1.35 & -28.1 & $170 \pm 29$ & $1937 \pm 17^{\mathrm{e}}$ & 19 \\
\hline \multicolumn{8}{|c|}{ Core FAK I02 } \\
\hline 6 & 12080 & leaflets / buds & 14 & -28.9 & $-756 \pm 34$ & $1998.5 \pm 3.5^{\mathrm{d}}$ & 5.5 \\
\hline 15 & 12081 & leaflets / buds & 9 & -29.1 & $-840 \pm 40$ & $1995.5 \pm 2.5^{\mathrm{d}}$ & 4.5 \\
\hline 20 & 12082 & leaflets / buds & 9.9 & -29.2 & $-825 \pm 33$ & $1996 \pm 2^{d}$ & 4 \\
\hline 30 & 12083 & leaflets / buds & 7.4 & -29.5 & $-1851 \pm 49$ & $1981.5 \pm 1.5^{\mathrm{d}}$ & 3.5 \\
\hline 40 & 12084 & leaflets / buds & 12.4 & -27.9 & $-976 \pm 34$ & $1957.5 \pm 1^{\mathrm{e}}$ & 3 \\
\hline 50.5 & 12085 & leaflets / buds & 8.6 & -28.7 & $146 \pm 45$ & $1937 \pm 18^{g}$ & 18 \\
\hline 60 & 12114 & leaflets / buds & 9 & -25.0 & $124 \pm 33$ & $1919 \pm 15^{g}$ & 15 \\
\hline 70 & 12086 & leaflets / buds & 8.7 & -28.0 & $-131 \pm 32$ & $1954.5 \pm 0.5^{\mathrm{e}, \mathrm{h}}$ & 2.5 \\
\hline 75 & 12087 & leaflets / buds & 10.8 & -27.9 & $66 \pm 47$ & $1890 \pm 15^{\mathrm{g}}$ & 15 \\
\hline 80.5 & 12088 & leaflets / buds & 8.9 & -28.3 & $121 \pm 32$ & $1881 \pm 10^{\mathrm{g}}$ & 10 \\
\hline
\end{tabular}

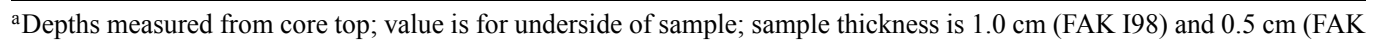
I02).

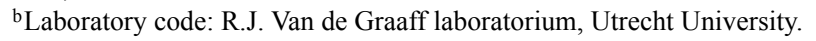

${ }^{\mathrm{c}}$ Total error consists of ${ }^{14} \mathrm{C}$ calibration error plus a 2-yr error factor covering sample thickness and transport/coring inaccuracies in samples calibrated with the bomb pulse.

${ }^{\mathrm{d}}$ Calibrated with bomb peak; data from Levin et al. (1994).

${ }^{\mathrm{e}}$ Calibrated with Cain and Suess (1974).

${ }^{\mathrm{f}}$ All material for Core FAK 102 is Taxodium distichum.

gWiggle-match with UWSY98, Stuiver et al. (1998).

${ }^{\mathrm{h}}$ Sample identified as outlier; not used in construction of age-depth model. 


\section{${ }^{14} \mathrm{C}$ Analysis}

Plant remains were visually inspected using a binocular microscope, and attached allochthonous organic material was removed. The samples were pretreated according to an acid-alkali-acid procedure (Mook and Streurman 1983) to remove contaminating humic acids. The prepared material was combusted and the carbon dioxide formed was subsequently converted into graphite. The graphite targets were analyzed by the AMS facility of Utrecht University (van der Borg et al. 1997). The $\delta^{13} \mathrm{C}$ values were obtained from analysis by the gas mass spectrometer at the Earth Sciences Department of Utrecht University, the Netherlands.

\section{Pollen and Loss-on-Ignition (LOI)}

Pollen from a weighed volumetric sediment sample was counted under the light microscope. A known amount of marker grains (Lycopodium clavatum) was added to the sample before standard palynological processing (Faegri and Iversen 1989) to allow for calculation of pollen concentration (grains $/ \mathrm{cm}^{3}$ ) per sample. At a constant pollen influx on a decadal timescale (Middeldorp 1982; Hicks 2001), stability of sedimentation rates can be assessed.

Sediment samples for loss-on-ignition (LOI) were dried for $12 \mathrm{hr}$ at $100{ }^{\circ} \mathrm{C}$, and combusted at $550^{\circ} \mathrm{C}$ and $1000^{\circ} \mathrm{C}$. Percent weight loss after each step is a measure of organic and carbonate fractions, respectively. Results of Dean (1974) show that organic material begins combustion at $200{ }^{\circ} \mathrm{C}$ and is completely ignited when temperature reaches $550{ }^{\circ} \mathrm{C}$.

\section{RESULTS}

Results of the AMS ${ }^{14} \mathrm{C}$ analysis are given in Table 1, represented as ${ }^{14} \mathrm{C}$ ages. The obtained $\delta^{13} \mathrm{C}$ values are between -32.6 and $-25.0 \%$, in agreement with the characteristic range of $\delta^{13} \mathrm{C}$ values in leaves and wood of canopy trees (Lockheart et al. 1998; Loader et al. 2003).

Results of the LOI and pollen counts are presented in Figure 2. As Australian pine (Casuarina equisetifolia) was introduced to Florida only after AD 1900 (Alexander and Crook 1974), the deepest occurrence of $C$. equisetifolia pollen in FAK 102 at $52.5 \mathrm{~cm}$ depth provides a maximum age of 100 calendar yr for the upper part of the core.

LOI at $550{ }^{\circ} \mathrm{C}$ (Figure 2) reveals a down-core decrease of the organic fraction, pointing to gradual decomposition of organic material. No sudden large influxes of clastic material were observed. Pollen concentrations show significant annual variability but no long-term trend; an apparent small decrease within the top $20 \mathrm{~cm}$ is in line with the expected low compaction at this level.

\section{Calibration and Age Models}

Twentieth century nuclear bomb testing created a distinct high-amplitude profile of elevated atmospheric ${ }^{14} \mathrm{C}$ levels, which can be used to calibrate recent samples into calendar yr. For better comparability with our ${ }^{14} \mathrm{C}$ ages, the ${ }^{14} \mathrm{C}$ data were converted into ${ }^{14} \mathrm{C}$ ages. This conversion creates a postAD 1950 calibration curve with negative ${ }^{14} \mathrm{C}$ ages (Figure 3a, atmospheric and tree-ring ${ }^{14} \mathrm{C}$ data from Northern Hemisphere rural areas, adapted from Cain and Suess 1976; Levin et al. 1994; Stuiver et al. 1998).

In case of multiple curve intercepts, stratigraphic information (order and depth of samples) was used to either assign data to the up- or down-slope of the bomb pulse (Figure 3a). Assuming stratigraphic order represents a true chronology in FAK I98 and I02, all ages below -100 BP could be accurately calibrated (Table 1$).{ }^{14} \mathrm{C}$ data calibrated in this manner have very small $1-\sigma$ errors $(1-2 \mathrm{yr})$ as a result 


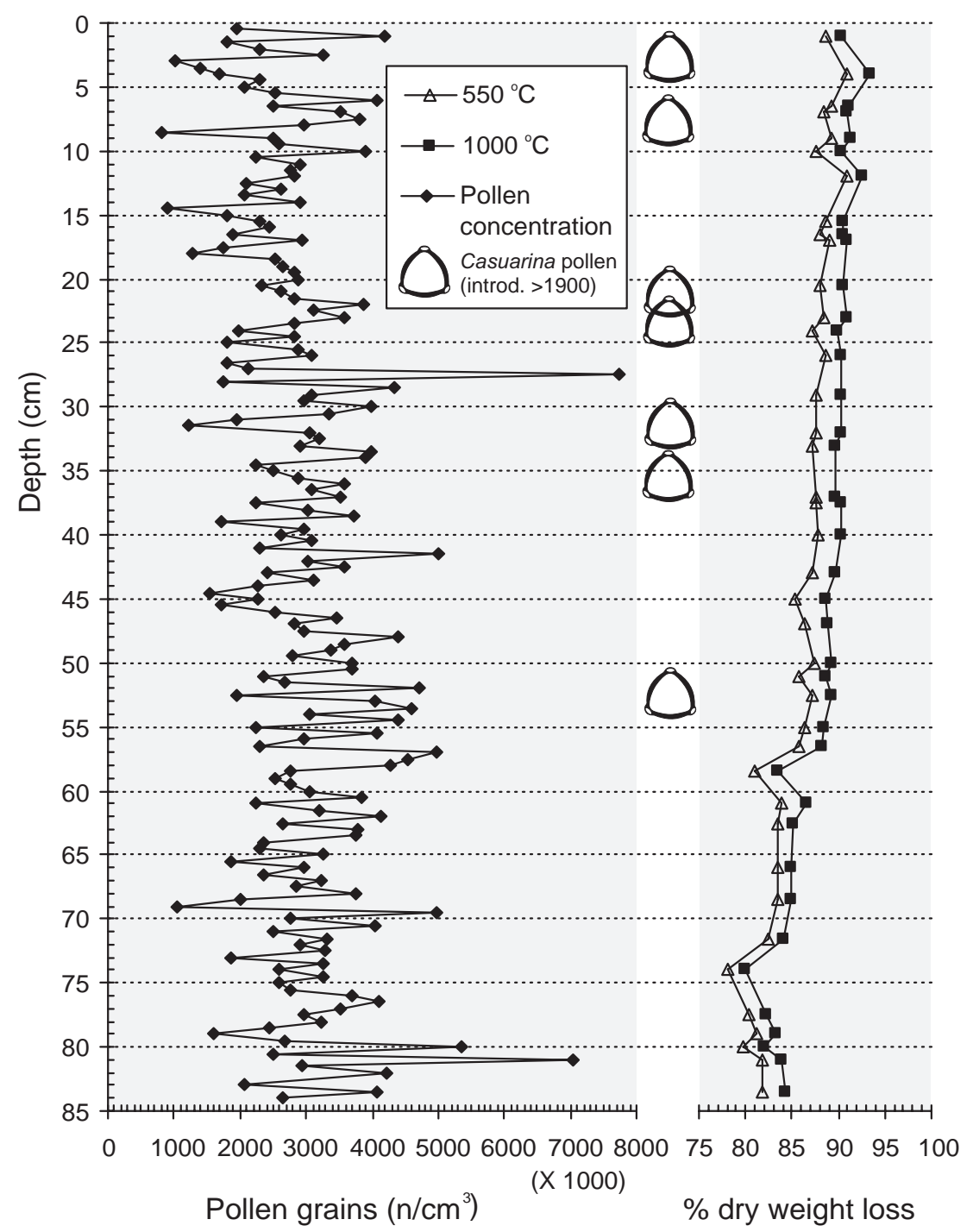

Figure 2 Loss-on-ignition (LOI) and pollen concentrations of core FAK I02. Occurrences of Casuarina equisetifolia pollen indicate post-AD 1900 sediment deposition.

of the well-determined ${ }^{14} \mathrm{C}$ bomb pulse. Especially evident is the fourfold better precision of the ${ }^{14} \mathrm{C}$ dates calibrated post-AD 1950 in comparison with the single pre-AD 1950 date in core FAK I98 (Figure 3b).

A smooth transition could be obtained between the pre- and post-AD 1950 sections of core FAK I02 (Figure 4a) by wiggle-matching the pre-bomb ${ }^{14} \mathrm{C}$ dates. The core was well compacted below $25 \mathrm{~cm}$ (taking pollen concentration and LOI data into account, Figure 2); thus, a linear accumulation rate could be expected below this level. Four ${ }^{14} \mathrm{C}$ data were calibrated by wiggle-matching with the highresolution UWSY98 curve (Stuiver et al. 1998). The best fit was obtained visually by varying the slope between and position of the ${ }^{14} \mathrm{C}$ dates relative to the calibration data. The accumulation rate thus found is a continuation of values encountered in the upper half of core FAK I02 $(0.53 \mathrm{~cm} / \mathrm{yr}$, 

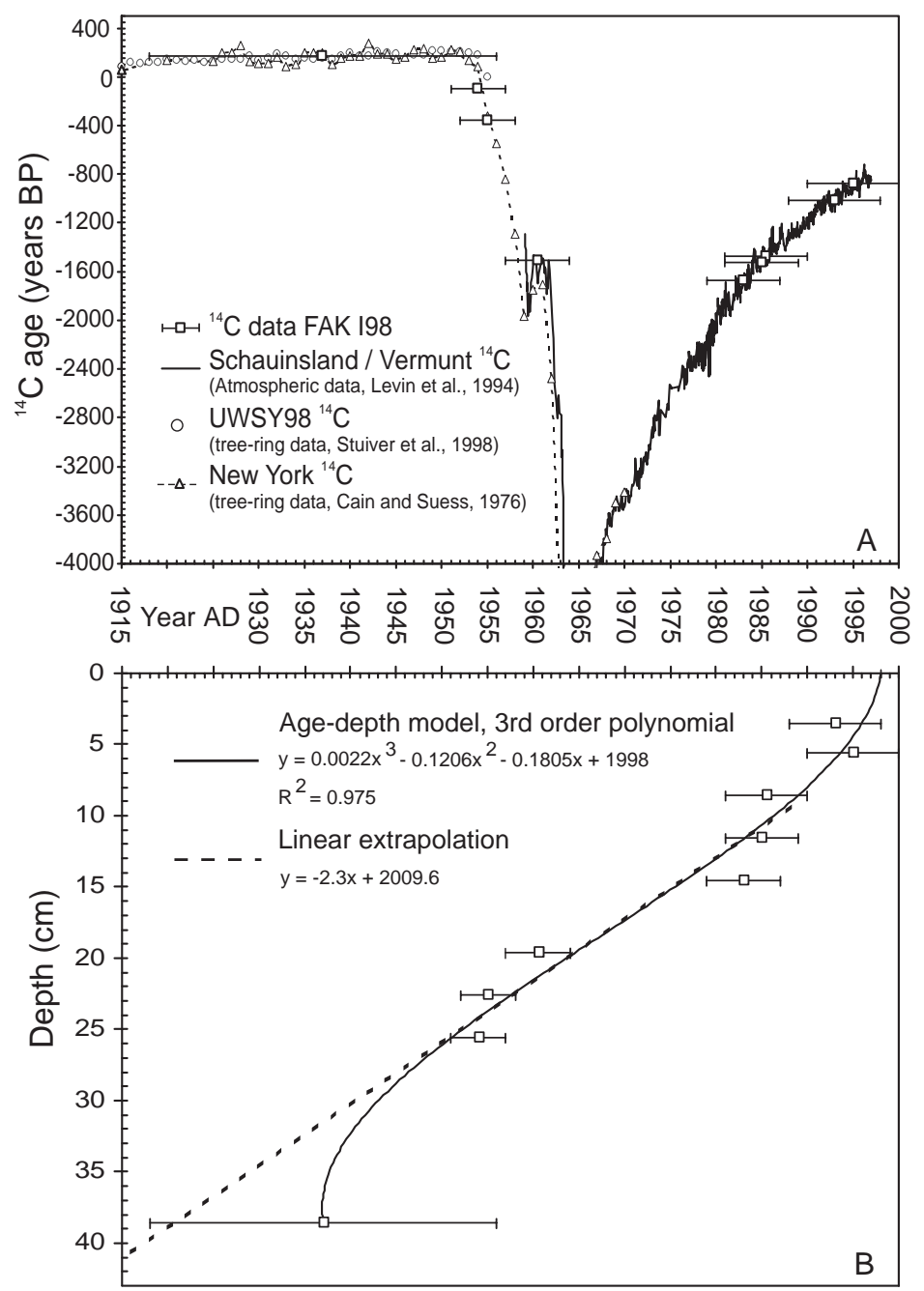

Figure 3 Modern ${ }^{14} \mathrm{C}$ bomb-peak anomaly used for calibrating recent samples of core FAK I98. (a) Calibrated samples are used to construct an age-depth model (b). $\mathrm{x}=$ depth in $\mathrm{cm}, \mathrm{y}=$ age in yr $\mathrm{AD}$ (axes inverted for comparison between Figures a and b). Errors shown contain an additional 2-yr factor for coring/sampling inaccuracies.

Figure $4 \mathrm{~b}$ ), in agreement with the stable sedimentation conditions below the top $25 \mathrm{~cm}$ and generally undisturbed setting of the site. Since no intercept is determined with wiggle-matching, error ranges were obtained by calculating the minimum value at which the ${ }^{14} \mathrm{C}$ measurement would fall outside the UWSY98 curve when shifted along the calendar axis.

Age models for both cores were obtained by fitting polynomial curves through the calibrated ${ }^{14} \mathrm{C}$ data, while fixing the core top at the year of collection (Figures $3 \mathrm{~b}$ and $4 \mathrm{~b}$ ). In FAK I02, 1 data point was excluded from the age model since it most likely represents an outlier. The resulting age determination range is 90 calendar yr for FAK I98 and 130 calendar yr for FAK I02 (see discussion). 


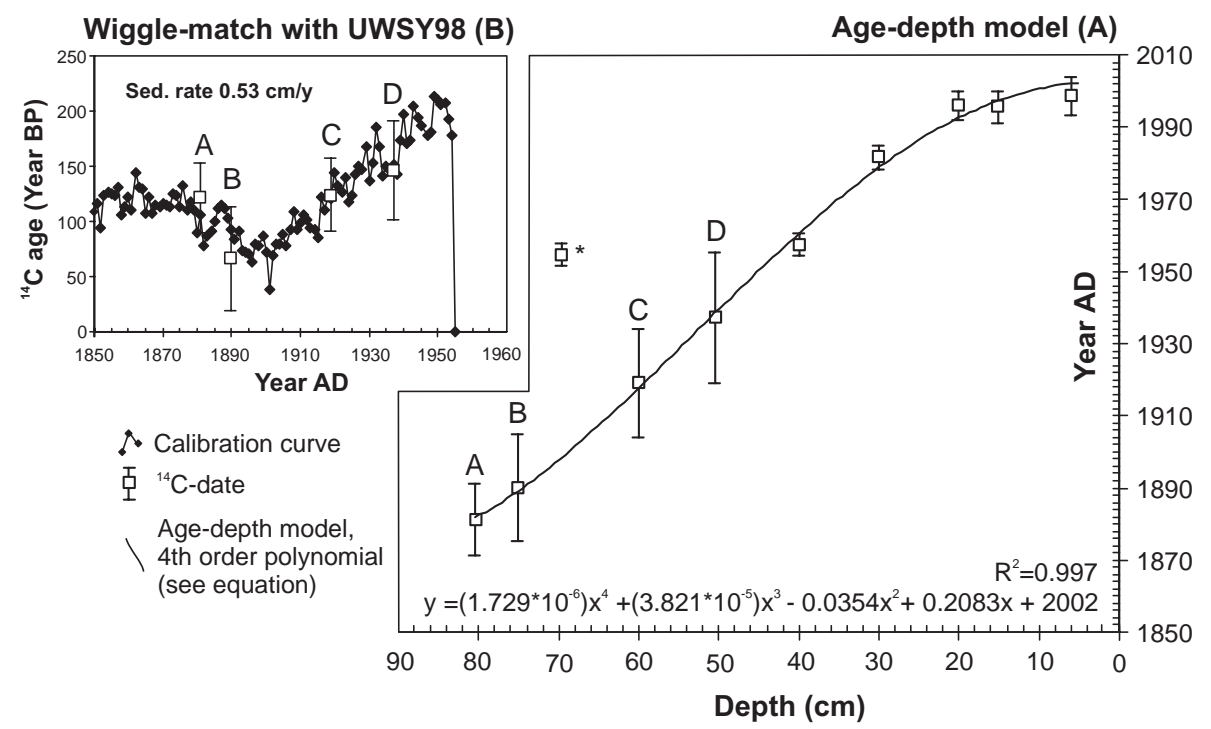

Figure 4 Age-depth model of core FAK I02 (a) containing data calibrated with bomb-peak and wigglematching approaches (Figure b, samples indicated A-D), $\mathrm{x}=$ depth in $\mathrm{cm}, \mathrm{y}=$ age in $\mathrm{yr} \mathrm{AD}$. Errors shown contain an additional 2-yr factor for coring/sampling inaccuracies when calibrated with the bomb-peak. The sample marked with an asterisk $(*)$ was considered an outlier and was not used for constructing the agedepth model (see discussion).

\section{DISCUSSION}

\section{Error Factors}

Since ${ }^{14} \mathrm{C}$ data calibrated with the bomb pulse anomaly have very small $1-\sigma$ errors $(1-2 \mathrm{yr})$, the accuracy of coring and sampling contributes significantly to the total error of the date. To account for these effects in the cores studied, a 2-yr error factor was added to the $1-\sigma$ interval of ${ }^{14} \mathrm{C}$ data calibrated by this method (Table 1). Possible artifacts of coring procedure, transport, sampling precision, and resolution are accounted for in this additional factor. The improvement by higher sampling resolution and precision of FAK I02 compared to FAK 198 (with $0.5-\mathrm{cm}$ and $1-\mathrm{cm}$ sampling intervals, respectively) is apparent from a better fit of the age-depth model in FAK I02.

Since in core FAK 198 only 1 data point is present in the pre-AD 1950 period, the lower limit of the age-depth curve cannot be accurately determined. Hence, an unrealistic age-reversal is present that cannot be explained from the ${ }^{14} \mathrm{C}$ and LOI data of the nearby core FAK I02. A linear extrapolation of the polynomial function was, therefore, used below $27 \mathrm{~cm}$. Based on the local sedimentation regime, this is considered the most realistic age model available for core FAK 198.

The outlier identified in FAK I02 is possibly due to down-sliding of individual leaves during coring. However, it most likely presents an isolated case since the outside of the core was removed during sample preparation.

The compaction difference between the unconsolidated top and lower sediment section is very apparent in the age models of both cores (Figures $3 b$ and $4 a$ ). This change is less obvious from the pollen concentrations in the FAK I02 core top (Figure 2). The pollen sub-sampling method used (small volumetric punch core) most likely caused some additional compaction, not fully reflecting the loose non-decomposed nature of the youngest sediment. The lower pollen concentration in the 
top is apparent, however, and therefore, in agreement with the core descriptions and the depth-models obtained.

Pre-bomb samples from areas with more than average fossil fuel combustion (i.e. cities, industries) can show a locally enhanced Suess effect (Cain and Suess 1976). For the early 20th century, these local effects could create additional uncertainty that cannot be resolved with high precision unless a calibration data set from the same area is present or industrial areas are avoided.

\section{Use of Method}

Although southern Florida is known to be highly sensitive to changes in the ENSO system, systematic paleoecological and paleoclimatological investigations on very high temporal resolution was hampered until now by the insufficient accuracy of age assessments for the peat deposits by conventional dating methods as ${ }^{137} \mathrm{Cs}$ and ${ }^{210} \mathrm{~Pb}$ (Cohen et al. 1999). By following the approach presented here, the homogenous organic-rich peat accumulations from this key area can be dated with far greater accuracy. The combined wiggle-match and bomb-pulse calibration of ${ }^{14} \mathrm{C}$ data of the peat deposits from South Florida has resulted in extremely accurate age models, especially for core FAK I02. Despite uncertainties about the different error factors mentioned above, the precision is still very high with maximum errors of $5 \mathrm{yr}$ for the post-AD 1950 period. The quality of the age assessments improves both the validation procedure for new proxies and their applicability.

Paleoecological proxies are commonly calibrated by comparison with surface samples as modern analogues. However, this modern analogue approach often suffers from error factors that arise from geographically widespread data sets. The high dating precision obtained here provides the opportunity for direct comparison of proxy data with measured historical meteorological records, thus enabling secure proxy validation and calibration in a restricted geographical area.

The high accumulation rates in both cores studied, with approximately $0.5 \mathrm{~cm} / \mathrm{yr}$ in the main part of the sections, allows the build-up of proxy records for the time beyond the range of instrumental measurements, with a temporal resolution high enough to detect changes occurring on multi-annual to sub-decadal scale.

In addition, we have obtained a smooth transition between samples calibrated by the bomb pulse and the UWSY98 data set. Therefore, the time frame where ${ }^{14} \mathrm{C}$ dating is commonly applied can be extended to include the 20th century.

The dating strategy outlined above thus meets the requirements for sound proxy validation and application, which is of prime importance in actualizing research fields dealing with dynamic climate systems that vary on multi-annual to centennial timescales, such as ENSO.

\section{ACKNOWLEDGEMENTS}

The authors wish to thank staff members of the Fakahatchee Strand Preserve State Park for their field assistance and overall support, in particular, Mike Owen and Ken Alvarez of the Florida Park Service. Ton van Druten, Wolfram Kürschner, Dan Zwartz, and Claire Schreurs are thanked for their fieldwork assistance. We greatly acknowledge the comments of the reviewer on the manuscript. This study was supported by the Council of Earth and Life Sciences, Netherlands Organization for Scientific Research. This is publication number 2004.05.02 of the Netherlands School of Sedimentary Geology (NSG). 


\section{REFERENCES}

Alexander TJ, Crook AG. 1974. Recent vegetational changes in southern Florida. In: Gleason PJ, editor. Environments of South Florida: Present and Past. Miami: The Miami Geological Society. p 61-72.

Appleby PG. 2001. Chronostratigraphic techniques in recent sediments. In: Last WM, Smol JP, editors. Basin Analysis, Coring and Chronological Techniques. Dordrecht, the Netherlands: Kluwer Academic. p 171203.

Birks HH, Birks HJB. 2003. Reconstructing Holocene climates from pollen and plant macrofossils. In: Mackay AW, Battarbee RW, Birks HJB, Oldfield F, editors. Global Change in the Holocene. London: Arnold publishers. p 342-57.

Burns LA. 1984. Productivity and water relations in the Fakahatchee Strand of South Florida. In: Ewel KC, Odum HT, editors. Cypress Swamps. Gainesville: University Press of Florida. p 318-33.

Cain WF, Suess HE. 1976. Carbon 14 in tree rings. Journal of Geophysical Research 81:3688-94.

Clymo RS. 1988. A high-resolution sampler of surface peat. Functional Ecology 2(3):425-31.

Cohen AD, Gage CP, Moore WS. 1999. Combining organic petrography and palynology to assess anthropogenic impacts on peatlands Part 1. An example from the northern Everglades of Florida. International Journal of Coal Geology 39:3-45.

Cronin TM, Dwyer GS, Schwede SB, Vann CD, Dowsett H. 2002. Climate variability from the Florida Bay sedimentary record: possible teleconnections to ENSO, PNA and CNP. Climate Research 19:23-45.

Dean WE. 1974. Determination of carbonate and organic matter in calcareous sediments and sedimentary rocks by loss on ignition: comparison with other methods. Journal of Sedimentary Petrology 44(1):242-8.

Faegri K, Iversen J. 1989. Textbook of Pollen Analysis. New York: Wiley and Sons. 340 p.

Hicks S. 2001. The use of annual arboreal pollen deposition values for delimiting tree-lines in the landscape and exploring models of pollen dispersal. Review of Palaeobotany and Palynology 117:1-29.

Jensen C, Kunzendorf H, Vorren K-D. 2002. Pollen dep- osition rates in peat and lake sediments from the Pinus sylvestris L. forest-line ecotone of northern Norway. Review of Palaeobotany and Palynology 121:113-32.

Levin I, Kromer B, Schoch-Fischer H, Bruns M, Munnich M, Berdau D, Vogel JC, Munnich KO. 1994. Delta ${ }^{14} \mathrm{CO}_{2}$ records from two sites in Central Europe. In: Boden TA, Kaiser DP, Sepanski RJ, Stoss FW, editors. Trends 93-A compendium of data on global change $\mathrm{p}$ 203-22 and online updates (Online Trends). Oak Ridge: Carbon Dioxide Information Analysis Centre. Oak Ridge National Laboratory.

Loader NJ, Robertson I, McCarroll D. 2003. Comparison of stable carbon isotope ratios in the whole wood, cellulose and lignin of oak tree rings. Palaeogeography, Palaeoclimatology, Palaeoecology 196:395-407.

Lockheart MJ, Poole I, van Bergen PF, Evershed RP. 1998. Leaf carbon isotope compositions and stomatal characters: important considerations for palaeoclimate reconstructions. Organic Geochemistry 29(4): 1003-8.

Middeldorp AA. 1982. Pollen concentration as a basis for indirect dating and quantifying net organic and fungal production in a peat bog ecosystem. Review of Palaeobotany and Palynology 37(3-4):225-82.

Mook, WG, Streurman HJ. 1983. Physical and chemical aspects of radiocarbon dating. In: Mook WG, Waterbolk HT, editors. Proceedings of the First International Symposium on ${ }^{14} \mathrm{C}$ and Archaeology. PACT 8:31-55.

Stuiver M, Reimer PJ, Braziunas TF. 1998. High-precision radiocarbon age calibration for terrestrial and marine samples. Radiocarbon 40(3):1127-51.

van der Borg K, Alderliesten C, de Jong AFM, Van den Brink A, de Haas AP, Kersemaekers HJH, Raaymakers JEMJ. 1997. Precision and mass fractionation in ${ }^{14} \mathrm{C}$ analysis with AMS. Nuclear Instruments and Methods in Physics Research B 123(1-4):97-101.

Watts WA, Hansen BCS. 1994. Pre-Holocene and Holocene pollen records of vegetation history from the Florida peninsula and their climatic implications. Palaeogeography, Palaeoclimatology, Palaeoecology 109:163-76. 